\title{
The Soviet Architecture Key Problems in the Second Half of the 1930s: on Materials of Plenums the Board of the Soviet Architects Union of the USSR
}

\author{
Yulia Starostenko ${ }^{1, *}$ \\ ${ }^{1}$ Scientific Research Institute of the Theory and History of Architecture and Urban Planning, Branch of the \\ Federal State Budget Institution "Central Scientific-Research and Project Institute of the Construction Ministry \\ of Russia", Moscow, Russia \\ *Corresponding author. Email: ystarostenko@yandex.ru
}

\begin{abstract}
The article focuses on the materials of nine Plenums of the Board of the Union of Soviet Architects of the Union of Soviet Socialist Republics (USSR), which took place in the second half of the 1930s in the period between the First All-Union Congress of Soviet Architects in 1937 and the beginning of the Great Patriotic War of the USSR. The published materials of the Plenums are very rarely used by specialists as sources for the study of Soviet architecture and have never been the subject of special research before. Meanwhile, the focus of each Plenum of the Board always turned out to be the most relevant problems of Soviet architecture at the current time. Therefore, they are important documents for understanding and comprehending the global processes that took place in the Soviet architecture of that time. In addition, the correlation of the materials of the Board Plenums with the materials of the First All-Union Congress of Soviet Architects in 1937 allowed us to see the congress not only as the final point in the Soviet architecture development in the 1930s, but also as the beginning of a new stage. The materials considered in the article show that at this moment starts the struggle against "excesses" ("izlishestva") in Soviet architecture.
\end{abstract}

Keywords: First All-Union Congress of Soviet Architects, Plenums the Board, Union of Soviet Architects of the USSR, Soviet architecture, Soviet town planning, 1930s.

\section{INTRODUCTION}

Despite the interest in the architecture of the USSR during the interwar period, the development of Soviet architecture in the late 1930s has been studied very fragmentally to date. As a rule, specialists focus on the first half of the decade. It is considered as a sort of postscript of the previous period of the Soviet architecture development, i.e. the period associated with the architecture of the Soviet avant-garde. At the same time, the First AllUnion Congress of Soviet Architects of USSR in 1937 is positioned as the final point of this postscript. The events that followed the congress

*Fund: The Reported study was funded by Science and Technology Development State Program of the Russian Federation within Program of Fundamental Researches of Ministry of Construction, Housing and Utilities of the Russian Federation and Russian Academy of Architecture and Construction Sciences. are usually not considered at all [1], [2], [3], [4], [5]. Among the probable reasons for this state of affairs, two factors can be noted. The first is the complexity and ambiguity of the events of the Soviet history of the second half of the 1930s, which are firmly connected in the public consciousness with the Moscow political processes of 1936-1938. The second factor is related to the fact that professional periodicals of the late 1930s were extremely politicized. The materials published in them were noticeably less informative than the materials of the first half of the decade. In addition, the number of publications of this kind significantly decreased after 1937. Thus, the range of available sources for analyzing the development of Soviet architecture in the second half of the 1930s is extremely limited.

Meanwhile, the First All-Union Congress of Soviet Architects of USSR in 1937 marked the 
beginning of a fundamentally new system of functioning of the Union of Soviet Architects of the USSR, an integral part of which were the Plenums the Board of the Union of Soviet Architects, held twice a year. In contrast to the materials of the congress, which were not fully published and were preserved mainly only in the form of transcripts and drafts reports, the materials of most of the Plenums were published. Despite the fact that these materials most likely were heavily edited, its make possible to identify the key problems faced by architects during this period, and to try to identify the main trends in the development of Soviet architecture of those years.

\section{FIRST ALL-UNION CONGRESS OF SOVIET ARCHITECTS OF USSR AND THE FIRST PLENUM BOARD OF THE UNION OF SOVIET ARCHITECTS OF THE USSR}

The first All-Union Congress of Soviet Architects of the USSR was held on June 16-26, 1937. Preparations for it took five years due to the constant postponement of the congress. During this time, not only the key principles of Soviet architecture have changed many times. The issues to be discussed by the congress have also undergone changes. Initially, the architects had to discuss the ways of development of Soviet architecture and its new style, which they had to create after the announcement of the results of an All-Union Open Competition for the design of the Palace of Soviets in 1932. Another important task was the approval for the work's principles of the Union of Soviet Architects, also established in 1932. In addition, the congress was planned to discuss many practical problems related to the design of various types buildings, the elaboration of projects for planning Soviet towns, building materials, the organization of architectural affairs, architectural and urban planning legislation, architectural education, etc. A special place was given to the coverage of the experience of foreign architecture. It was planned that some of the reports would be heard in plenary sessions, and all special reports would be discussed in specialized sections.

The postponement of the congress led to frequent adjustments to the program and reports, which had to correspond to the most relevant guidelines of the party and the government. Gradually, coverage of the experience of foreign architecture was excluded from the congress program, although the task of inviting the leading architects of Europe and America to the congress remained relevant [6]. One of the key tasks was to substantiate the concept of "socialist realism", which in the mid-1930s came to Soviet architecture from literature. In 1936, after launching a campaign against "formalism" in music, a similar campaign was launched in relation to architecture [7]. Adopted in the same year, the resolution of the party and the government "On improving the construction business and saving in construction" led to the emergence of new slogans about the development of modern construction equipment by Soviet architects. After the adoption of the new Constitution of the USSR at the end of 1936, the problem of "folk character" ("narodnost") in Soviet architecture began to be actively discussed in architectural journals.

All these questions, of an ideological rather than a practical nature, were bound to be included in the program of the congress. Thus, the preparation of the congress took place under the influence of two mutually exclusive aspirations for those years: the desire to discuss issues relevant to the professional community and the desire to make a "politically correct" event. While the program of the congress maintained the division of reports into plenary and sectional ones, the balance between ideology and discussion of the practical problems of Soviet architecture was to some extent observed. However, the watchful attention on the event from the party leadership of the country led to the rejection of sectional reports, which excluded the possibility of professional discussion.

Each plenary report at the congress was assigned a very specific role. The program speech of the actual head of the Soviet architects K. S. Alabyan set the general direction of the congress. It propagandized the fight against "formalistic trickery" ("formalisticheskoe triukachestvo") in architecture and town planning, proclaimed the embodiment of the ideals of "socialist realism" truthfulness and simplicity; etc. The report of the architect of the "old school" A.V. Shchusev was supposed to justify the choice of classical architecture as a model, and explain how this choice is combined with the ideas of folk and national architecture. He also had to show how an architect should work with all these "sources of inspiration". The report of N.Y. Kolli was a presentation of the history of the formation of Soviet architecture. It consistently held the idea that the period of the 1920 s, i.e. the era of the architectural avant-garde, was an unfortunate 
misunderstanding. In the report of G. A. Simonov and A. G. Mordvinov, devoted to the issues of housing construction, much was also said about the evil caused to Soviet architecture by "formalism". However, the speakers were forced to raise such "inconvenient" issues as poor organization of the design process, unsatisfactory quality of building materials, primitive work of builders, etc. The town-planning reports of S.E. Chernyshev and L.A. Ilyin, who discussed the achievements of Soviet town-planning, echoed the general reports. However, their authors could not but touch on the problems, without pointing to which it was impossible to explain the low pace of reconstruction of Soviet cities and the lack of "cities-ensembles", since the creation of which was one of the priorities of Soviet urban planning after $1932^{1}$.

The result of the congress was the proclamation the victory of the architecture of "socialist realism" over "formalism" and the approval of the new organizational structure of the Union of Soviet Architects of the USSR, which for this purpose acted under the leadership of the Organizing Committee responsible for the preparation of the congress. The congress held elections of the Board members of the Union of Architects, which included many notable architects of Moscow, Leningrad and the Union republics. The first plenum of the newly elected board, which was held on the second day after the end of the Congress June 28, 1937, was essentially organizational. The Presidium of the Board, the Secretariat of the Board (the actual leadership of the Union of Soviet Architects), and the Audit Commission were selected. The plenums Board were considered as a platform for discussing the most pressing issues of Soviet architecture and had to be held fairly regularly, which was implemented in practice. However, reading out specially prepared reports, by analogy with the congress, actually excluded a live discussion at the plenums.

Of the eight pre-war plenums Board (not counting the first organizational one) held in 19371941 , three were devoted to mass construction, two to the development of Soviet town planning, one to the Palace of Soviets design, one to the art industry problems, and another to the work of young architects.

1. The analysis is based on the materials of the congress, stored in the Russian State Archive of Literature and Art (RGALI): RGALI, f. 674, op. 2, dd. 30-39.

\section{PLENUMS BOARD OF THE UNION OF SOVIET ARCHITECTS DEVOTED TO MASS CONSTRUCTION ISSUES}

From the above review of the board's plenums, it follows that the issues of mass construction were most often brought up for discussion. The problems of economy in construction, typification and standardization, as well as industrialization, have been discussed in one form or another since the mid-1920s, i.e. since the time when began work for develop the principles of long-term planning of the national economy, which eventually led to the emergence of a system of five-year plans ("pyatiletka"). By the mid-1930s, in connection with the implementation of grandiose projects, including large-scale industrial construction, reconstruction of Moscow and many others, these problems became particularly acute. In December 1935 , at the first meeting on construction issues in the Central Committee of the CPSU(b), was proclaimed a course for mechanization and industrialization of construction. In February 1936, these adjustments were fixed in the already mentioned resolution of the Central Committee of the CPSU(b) and the SNK of the USSR "On improving the construction business and on reducing the cost of construction". It was this resolution gave rise to the Second Plenum Board of the Union of Soviet Architects, dedicated to the design and construction of residential buildings, in December 1937.

The Second Plenum Board in its resolution stated that "we still build houses too slowly, too expensive, not convenient enough for housing and not always beautiful" [8]. It required a revision of building norms and the organization of factory production of standard structures that would allow for the rapid construction of the building structural framework. However, the architects opposed any attempts to standardize and typify the facades of residential buildings. They did not want to refuse the individual solutions of facades and insisted that the main wall materials of mass construction remained bricks and concrete blocks of different sizes. The architects explained the need to preserve individual solutions by the requirements of creating an architectural ensemble, the creation of which they associated with the design of unique buildings. The Second Plenum Board in its resolution emphasized that "the typification of an entire residential building is appropriate only in certain cases, in the conditions of the development of new 
settlements" [9]. In other cases, the architects proposed to limit the use of standard layouts of sections of residential buildings and some structural details and elements.

As one of the arguments in favor of their proposals, the architects used the fact that in the USSR there is still no full-fledged construction industry, the creation of which was provided for by the decree "On improving the construction business and on reducing the cost of construction". However, in March 1938, the Committee for Construction Affairs was formed under the SNK of the USSR. A year later, at the end of May 1939 it was transformed into the All-Union People's Commissariat for Construction of the USSR. One of the first results of the committee's activities was the government resolution "On standard projects of nurseries and maternity hospitals", issued in June 1938. It emphasized the need to "approve standard projects that provide for a significant simplification and reduction in the cost of construction", and projects that "contain excesses" ("izlishestva") were called "incorrect and contain sabotage perversions" [10].

The reaction to this decision was the Fourth Plenum Board of the Union of Soviet Architects in December 1938 - January 1939. Its key theme was formulated as "Mass construction. Schools, kindergartens, nurseries, maternity hospitals". The Plenum noted a very deplorable state of affairs in the field of mass construction, the obsolescence of the projects that use it, and the need to start this work virtually anew with the adjustment of the existing standards. At the same time, no aesthetic aspects of the design were discussed, except for the indication that the standard projects of 1939 have unfinished facades. It is significant that the Plenum did not defend the right to individual design of objects of social and cultural services of this category. The reason was, most likely, two circumstances: on the one hand, these types of buildings did not arouse strong interest among architects, and on the other, the development of standard designs of school buildings by that time had already become a normal practice [11].

In July 1939, the requirements announced a year earlier in relation to kindergartens, nurseries and maternity hospitals were extended to housing construction. In the resolution of the SNK of the USSR "On standard housing construction projects", the People's Commissariat for Construction and the Moscow City Council were instructed to develop projects for standard sections of residential buildings and "to prevent unjustified architectural excesses (high parapets, gables, excessively large cornices, high arches, loggias, etc.)" [12]. And again, the resolution was followed by the Sixth Plenum Board of the Union of Soviet Architects, held in December 1939 and dedicated to the issues of high-speed construction. This time, the resolution of the plenum noted, "high-speed construction methods, the use of prefabricated structures and standard parts do not at all narrow the architectural and compositional opportunities of designers". The architect was obliged to "extract the maximum artistic expressiveness from these technical conditions and materials, avoiding simplified solutions and impersonal monotonous compositional schemes" [13].

The change in rhetoric was largely due to the fact that at this plenum, the architects already had something to present as a positive experience of building according to the technology that they adhered to. In 1938, the architect A. G. Mordvinov tested the flow-speed method of construction of residential buildings by this method on Bolshaya Kaluzhskaya Street [14]. It was based on a clear organization of all construction processes, the lack of which was often encountered by Moscow construction sites of that time. The usual practice was to allocate land for development to various departments that did not have enough funds to implement projects. Often the construction was limited a fence installation on a designated site. In the case of construction, organized on the initiative of A. G. Mordvinov, the work was carried out centrally at the expense of the Moscow City Council, with the involvement of Moscow construction organizations. This gave a unique opportunity for a one-time complex development of the city avenue territory, although in fact it was just about a competent and rational organization of the construction process. However, despite all the efforts, this experience was a demonstration of what architects were so afraid of when introducing new construction technologies. A limited number of houses types with similar facades in their eyes contradicted the task of creating Soviet "cityensembles". This construction was supposed to demonstrate that mass architecture requires not simplification, but qualitatively different solutions. Its exemplary character made it possible to significantly enrich the architecture of the houses, through the use of decorative elements, but the general sense of repetitiveness of the houses could not compensate by the decorative elements. As a result, this experience remained unique for Moscow 
in those years, and could not stop the building industry that was gaining momentum, focused on standard and mass solutions.

Another plenum of the board, which discussed issues related to the problems of mass construction, was the Eighth Plenum Board of the Union of Soviet Architects. It was held in December 1940 and was dedicated to the art industry. It was about the need to organize the mass production of various interior items due to the fact that the mass construction of residential buildings seemed to be a matter of the near future [15]. At that time such productions of furniture, lamps, etc. actually did not exist. The holding of the Plenum only emphasized the urgency of the task and the scale of the problem.

\section{PLENUMS BOARD OF THE UNION OF SOVIET ARCHITECTS ON URBAN PLANNING}

The development of Soviet town planning was discussed at two Plenums Board of the Union of Architects. The Third Plenum in July 1938 was devoted to general issues of planning and construction of cities of the USSR. At the Seventh Plenum in July 1940, dedicated to the fifth anniversary of the adoption of the resolution of the party and the government "On the General Plan for the reconstruction of Moscow", were discussed architectural and town planning issues of the reconstruction of the Soviet capital.

In contrast to the discussed plenums on mass construction, the plenums on town planning clearly demonstrated the crisis in this area. The range of problems that specialists had to face in the second half of the 1930s when developing planning projects, as a whole, was formed even before the congress of 1937. The resolution "On the General Plan for the Reconstruction of Moscow" continued to be considered as the main town planning document. Legislation that allowed the development of urban planning projects and their systematic implementation, in fact, did not exist. Moreover, the architects were deprived of such key documents as plans for the industrial and economic development of cities, which allowed them to avoid endless revisions of projects and subsequent alterations of the already ongoing construction. But even the developed plans were often ignored, and therefore at the Third Plenum Board of the Union of Soviet Architects in 1938, architects demanded from local leaders "the strictest observance of discipline in the development of the city, unconditional subordination of their construction to the general plan" [16]. The Seventh Plenum Board of the Union of Architects, held two years later, was a clear demonstration of another problem. Town development projects were carried out extremely slowly, often inconsistently, but, as before, it was impossible to talk about it openly, and therefore the speakers were forced to retell the text of the 1935 resolution, which was already very far from the real Moscow construction [17].

\section{PROBLEMS OF CONSTRUCTION OF THE PALACE OF SOVIETS AND ARCHITECTURAL EDUCATION AT THE PLENUMS BOARD OF THE UNION OF SOVIET ARCHITECTS}

The two remaining plenums suggested topics that might seem rather random, but this was far from the case. The reason for the convocation of the Fifth Plenum Board of the Union of Soviet Architects in the summer of 1939, dedicated to the Palace of Soviets and its architecture, was the resolution of the XVIII Congress of the CPSU(b) on the report of V. M. Molotov, who presented the plan of the third five-year plan. The decision of the party congress ordered to complete by the end of the third five-year plan, i.e. by the end of 1942, the main works on the construction of the Palace of Soviets. For the leadership of the Union of Soviet Architects, this was an occasion to once again raise the issue of the "synthesis of the arts", which was so actively discussed in the mid-1930s, but has not lost its ideological significance. It is no accident that the key report of the plenum of the chief architect of the Palace of Soviets, B. M. Iofan, was called "The Construction of the Palace of Soviets and the Commonwealth of Arts" [18].

The ninth plenum of the Board of the Union of Soviet Architects in May 1941 was devoted to architectural education and summing up the first results of the activities of young architects who had already studied at the Moscow Architectural Institute, and not at VKHUTEMAS, known for its avant-garde ideas. The choice of this topic was explained by the fact that a year earlier the Academy of Architecture of the USSR had established the work of postgraduate studies and began defending dissertations. In other words, architectural education has reached a qualitatively new level, and architectural science has become an important component of the life of the professional community. However, the texts of the reports at the 
Plenum were very general and painted an idyllic picture of the education of young architects, very far from the tasks that were discussed at other plenums [19].

\section{CONCLUSION}

Summarizing the above, it can be noted that in 1937, after the First All-Union Congress of Soviet Architects of the USSR, the era of discussions and experiments in Soviet architecture became a thing of the past. The emphasis on practical issues at the plenums of the Board of the Union of Soviet Architects of the USSR in 1937-1941 shows that the struggle against "formalism" was considered complete, and the definition of the architecture of "socialist realism" was found. These issues, of course, were raised in one way or another at the Plenums Board of Soviet Architects of the USSR, but they were not in the focus of attention, as at the All-Union Congress of Soviet Architects of the USSR in 1937.

Thus, on the one hand, the issues submitted for discussion by the plenums of the Board of the Union of Architects of the USSR in 1937-1941 reflected the key problems facing Soviet architects. And so today, the analysis of the materials of the plenums allows us to clearly trace the formation of those trends in the development of Soviet architecture, which will fully manifest themselves in the 1940s - the first half of the 1950s. On the other hand, the materials of the plenums clearly demonstrate what led to the need to follow the guidelines of the party and the government, the fight against deviations from the general course, and so on led to. So necessary in the face of new challenges, professional discussion on topical issues of the theory and practice of architecture in these years was virtually absent. Although the resolutions of some of the plenums contained quite specific proposals that expressed the aspirations of the architects, it was obvious that the architectural community could not establish a dialogue with the "customer" (represented by the party and the government) and the new structures responsible for the development of the construction industry.

\section{AUTHORS' CONTRIBUTIONS}

The author's contribution to the study of the stated topic is a detailed analysis of the materials of the plenums of the Board of the Union of Architects of the USSR, held in 1937-1941. The complex of these materials has never been the object of special research before. Its study allowed seeing the Soviet architecture of the second half of the 1930s not only as a set of architectural structures erected at that time, but also as a series of large processes associated with the revision of the key attitudes of the professional activity of Soviet architects.

\section{REFERENCES}

[1] H. D. Hudson Jr., Blueprints and Blood: The Stalinization of Soviet Architecture, 19171937, Princeton, Princeton University Press, 1994 [in English].

[2] A. N. Selivanova, Postconstructivism: Power and Architecture in the 1930s in the USSR (Postkonstruktivizm: Vlast' i arkhitektura V 1930-e gody v SSSR), Moscow, BuksMArt, 2018 [in Russian].

[3] D. Udovički-Selb, Between modernism and socialist realism: Soviet architectural culture under Stalin's revolution from above, 19281938, in: Journal of the Society of Architectural Historians, vol. 68, issue 4, December 2009, pp. 466-495 [in English].

[4] V. Hnídková, Moskva 1937. Architecture and propaganda in Western perspective (Architektura a propaganda v Západní perspective), Praha, Prostor - architektura, interi 2018 [in Czech].

[5] D. Udovički-Selb, Soviet Architectural AvantGardes: Architecture and Stalin's Revolution from Above, 1928-1938, London, Bloomsbury Visual Arts, 2020 [in English].

[6] E. V. Konysheva, "Stormy applause, everyone gets up": foreign guests at the First All-Union Congress of the Soviet Architects ("Burnye aplodismenty, vse vstaiut": inostrannye gosti na pervom vsesoiuznom s'ezde sovetskikh arkhitektorov), in: Questions of the history of world architecture (Voprosy vseobshchei istorii arkhitektury), vol. 2, 2018, pp. 228-246 [in Russian].

[7] Y. D. Starostenko, From "confusion instead of music" to "cacophony in architecture": the struggle against formalism in Soviet architecture in the 1930s (Ot "sumbura vmesto muzyki" k "kakofonii v arkhitekture": bor'ba s formalizmom v sovetskoi arkhitekture v 1930e gg.), in: Scientific schools in musicology of the XXI century: to the 125th anniversary of 
Gnessin educational institutions: Materials of the International Scientific Online Conference, November 24-27, 2020 (Nauchnye shkoly v muzykovedenii XXI veka: k 125-letiiu uchebnykh zavedenii imeni Gnesinykh: Materialy Mezhdunarodnoi nauchnoi onlainkonferentsii, 24-27 noiabria 2020 goda), Moscow, 2020, pp. 407-415. URL: https://gnesin-academy.ru/wpcontent/documents/nauka/Nauchnie_shkoli_v_ musikovedenii_Sbornik_statey_2020.pdf (access: 02.02.2021) [in Russian].

[8] Housing. Issues of design and construction of residential buildings. Proceedings of the II Plenum Board of the Union of Soviet Architects of the USSR, December 23-27, 1937 (Zhilishche. Voprosy proektirovaniia i stroitel'stva zhilykh zdanii. Materialy II Plenuma Pravleniia Soiuza sovetskikh arkhitektorov SSSR, 23-27 dekabria 1937 g.), Moscow, 1938, pp. 124 [in Russian].

[9] Ibid, pp. 129.

[10] Resolution of the SNK of the USSR "On standard projects of nurseries and maternity hospitals" (Postanovlenie SNK SSSR "O tipovykh proektakh iaslei i rodil'nykh domov"), in: Collection of resolutions and orders of the Government of the USSR for 1938 (Sobranie postanovlenii i rasporiazhenii pravitel'stva SSSR za 1938 g.), Moscow, 1945, pp. 501 [in Russian].

[11] Mass construction. Schools, kindergartens, nurseries, maternity hospitals. Proceedings of the IV Board Plenum of the Union of Soviet Architects of the USSR, December 25, 1938 January 3, 1939 (Massovoe stroitel'stvo. Shkoly, detskie sady, iasli, rodil'nye doma. Materialy IV plenuma Pravleniia Soiuza sovetskikh arkhitektorov SSSR, 25 dekabria 1938 - 3 ianvaria 1939 goda), Moscow, 1939, pp. 104-113 [in Russian].

[12] Resolution of the SNK of the USSR "On standard housing construction projects" (Postanovlenie SNK SSSR "O tipovykh proektakh zhilishchnogo stroitel'stva"), in: Collection of resolutions and orders of the Government of the USSR for 1939 (Sobranie postanovlenii i rasporiazhenii pravitel'stva SSSR za 1939 g.), Moscow, 1945, pp. 485 [in Russian].
[13] High-speed construction. Materials of the VI Plenum Board of the Union of Soviet Architects of the USSR, December 13-16, 1939 (Skorostnoe stroitel'stvo. Materialy VI Plenuma Pravleniia Soiuza sovetskikh arkhitektorov SSSR, 13-16 dekabria 1939 g.), Moscow, 1940, pp. 119 [in Russian].

[14] High-speed construction of 23 residential buildings in Moscow (Skorostnoe stroitel'stvo 23 zhilykh domov v Moskve), in: Architecture of the USSR (Arkhitektura SSSR), no. 5, 1939, pp. 14-18 [in Russian].

[15] The condition of the art industry and the struggle for the artistic quality of industrial products. Resolution of the VIII Plenum Board of the Union of Soviet Architects of the USSR, December 26, 1940 (Sostoianie khudozhestvennoi promyshlennosti i bor'ba za khudozhestvennoe kachestvo promyshlennykh izdelii. Rezoliutsiia VIII plenuma Pravleniia Soiuza sovetskikh arkhitektorov SSSR, 26 dekabria 1940 g.), Moscow, 1941 [in Russian].

[16] Planning and construction of cities of the USSR. Proceedings of the III Plenum of the Board of the Union of Soviet Architects of the USSR, July 7-11, 1938 (Planirovka i stroitel'stvo gorodov SSSR. Materialy III Plenuma Pravleniia Soiuza sovetskikh arkhitektorov SSSR, 7-11 iiulia 1938 g.), Moscow, 1938, pp. 10 [in Russian].

[17] Architectural issues of the reconstruction of Moscow. Proceedings of the VII Plenum of the Board of the Union of Soviet Architects of the USSR, July 8-12, 1940 (Arkhitekturnye voprosy rekonstruktsii Moskvy. Materialy VII plenuma Pravleniia Soiuza sovetskikh arkhitektorov SSSR, 8-12 iiulia 1940 g.), Moscow, 1940 [in Russian].

[18] Architecture of the Palace of Soviets. Proceedings of the V Plenum Board of the Union of Soviet Architects of the USSR, July 1-4, 1939 (Arkhitektura Dvortsa Sovetov. Materialy V plenuma Pravleniia Soiuza sovetskikh arkhitektorov SSSR, 1-4 iiulia 1939 goda). Moscow, 1939 [in Russian].

[19] Proceedings of the IX Plenum of the Board of the Union of Soviet Architects of the USSR (Materialy IX plenuma Pravleniia Soiuza sovetskikh arkhitektorov SSSR), no. 1, May 28, 1941; no. 2, May 29, 1941, Moscow, 1941 [in Russian]. 